\title{
A Remark on the Constitution of Larval Syllids.
}

\author{
By
}

Yô K. Okada.

With 5 Figures in the Text.

The facts of Polychæte embryology inform us that the change of the trochophore into the perfect worm consists, first of all, in a growing out of the posterior section of its body and a gradual reduction of the anterior part, segmentation appearing at the same time. This phenomenon depends upon a marked change of the mesodermal bands, situated on each side of the intestine. Each of them is separated into two cell-layers, which spread out toward the mid-ventral and mid-dorsal lines. Then a segmentation makes its appearance in them, proceeding from in front backwards, and almost simultaneously the two layers of the bands separate from each other, by the formation of a cavity in each section or segment. That new segments are gradually formed one after the other, and from before backwards, in the hinder part of the growing body, holds true universally, but, at the extreme end a segment has been individualised from the first, or at a very early phase of the segmentation, and this segment does not divide again even to the end of development. In this way the pygidium is formed, and it represents the posterior individual portion of the trochophore. The growth of Polychæte-larvæ is therefore anteanal and entirely in the penultimate segment.

Syllids pass the earliest phases of their development within the eggcapsule, and the larvæ hatch out generally as metatrochophores, or even at the commencement of parapodial formation in the anterior secondary divisions or segments (nectochata). The origin of these new segments follows, of course, the law of embryonic development mentioned in the last paragraph ; this is, however, after the 9-meric stage in this family of Polychætes.

The larva of this stage has generally the following morphology : the prostomium has three appendages and two pairs of eyes on the dorsal aspect, but very frequently no palpi on the ventral side. In the second segment the dorsal cirri are well marked, but the ventral are either in an early stage of development or are not yet formed. The five following metameres are each provided with a pair of parapodia or those of the hinder part are replaced by bundles of setæ. Generally there are dorsal 
cirri too. The larvæ of Exogoninæ are without the dorsal cirri in the second setigerous segment, and this fact seems quite constant within this sub-family (see Viguier's pl. V, fig. 52, 1884, or Malaquin's pl. XIV, fig. 32, 1893, for example). The eighth section of the body is the growth zone, and the ninth is the pygidium, which carries the already elongated caudal cirri.

Before this stage the larva, when typical, consists of seven segments, three being setigerous. Most larvæ of the Exogoninæ have this constitution (see Viguier's pl. IV, fig. 33, and Malaquin's pl. XIV, fig. 3).
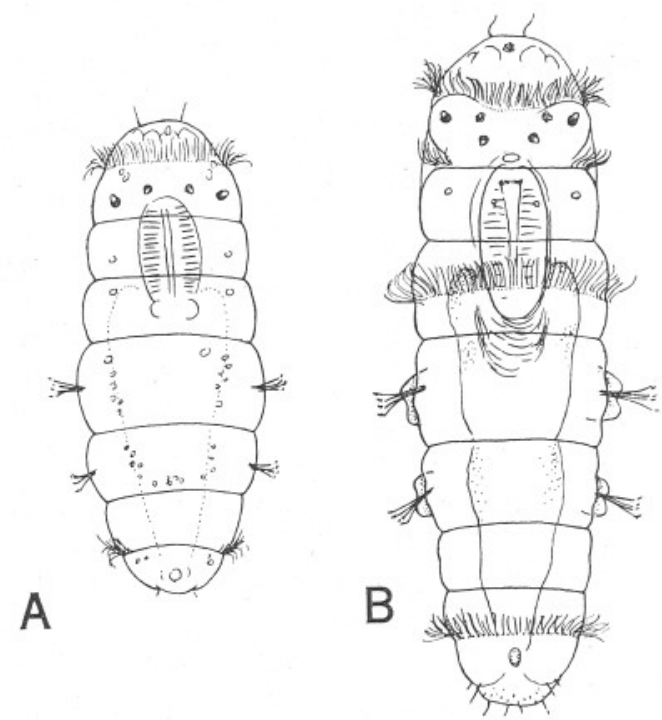

FIя. 1.-Larvæ of A. longeferiens, (A) one-day old and (B) four-day old, from Mrs. Sexton's sketches.

The growth zone being always penultimate, it forms here the sixth section of the body. However, a metameric number less than seven is usually normal, especially in the other sub-families, some being bi-setigerous (see Malaquin's pl. XIII, fig. 20 ; Herpin's pl. IV, fig. 92, 1925) and others mono-setigerous (see Malaquin's pl. XIV, fig. 17A; Herpin's pl. VI, fig. 124; Greeff's pl. XIV, fig. 36, 1879). In such cases it is generally stated that the position of the setæ represents the third and fourth segments in the first instance, or the third segment alone in the second. My own view in respect to the position of the setæ in the atypical 7-meric larvæ of Syllids is different.

Dating back to 1914 (Feb. 18th) a Sacconereis of Autolytus longeferiens was captured by the tow-net off the Eddystone, S.W. by W., one mile (the Plymouth district). It carried two ovigerous sacs on its mid-ventral 
surface, from which swimming larvæ were hatched out on March 2nd. Mrs. E. W. Sexton sketched several of them very faithfully from the living specimens. According to these drawings the larva of one day old, which is shown in Fig. 1A, judging from its matameric number, exactly corresponds to the 7-meric stage of the standard development. The larva in question is, however, bi-setigerous, pale yellow in colour and about $0 \cdot 25 \mathrm{~mm}$. in length. The cephalic section has two pairs of reddish-brown eyes and bears a ring of long cilia (akrotroch) in front of them. The telotroch (paratroch) appears on each side between the last two segments. The fourth section of the body is larger than any other, and this and the next segment are provided with setæ. The stomodeal invagination reaches the middle of the third segment and the intestine also commences from this position. It is almost impossible to doubt, unless we are deceived as to the exactitude of the sketch, that the anterior pair of the setose-bundles is formed in the fourth section, which corresponds to the second setigerous segment of later development, and the same is the case in the adult.

After three days the larva (Fig. 1B) (sketched March 4th) measures naturally more $(0.35 \mathrm{~mm}$.) than before, and several important changes have crept into its structure. A band of cilia appears in the middle of the third segment and surrounds it like a girdle (interparatroch). The telotroch is now complete all the way round, its position being between the last two segments as before. Another new feature is a band of cilia on each of the hinder borders of the cephalic section, just behind the position of the eyes (according to my reinvestigation this band is continuous on both sides, on the ventral side certainly, and it is almost without doubt the prototroch), and a new segment appears between the posterior setigerous segment and the penultimate growth zone. The pharynx and the intestine are as before. The setæ of the fourth and fifth segments are now elongate, and a primitive parapodium is beginning to be associated with each bundle of them. But neither of these organs is found in the third segment. This fact finally led us to investigate whether the segment bearing the interparatroch is really the third section of the larva, that gives rise later to the first setigerous segment of the adult worm. There is no sketch of the more advanced stages and no data are available to solve the problem.

Mr. D. P. Wilson has observed similar larvæ of Autolytus pictus in earlier phases than those of Mrs. Sexton, and by means of Mr. Wilson's observation we can trace two stages back. At the time of hatching (April 19th, 1927) the larva (Fig. 2A) was $0.25 \mathrm{~mm}$. long and pale green in colour. There were neither appendages nor setæ in the body-segments. The eyes, four in two pairs, were only distinct in the head section, each provided with a prominent lens. The anterior lenses are directed forwards 
and outwards, while the posterior look outwards and backwards. As a whole the larva is elongate and pyriform, the wider end being anterior, and it is divided into five sections. The prototroch is well marked and is situated behind the eyes. It is transversely straight on the dorsal surface, while, ventrally, it is continuous and arches forwards in front of the mouth opening. There is a band of long cilia on each side of the

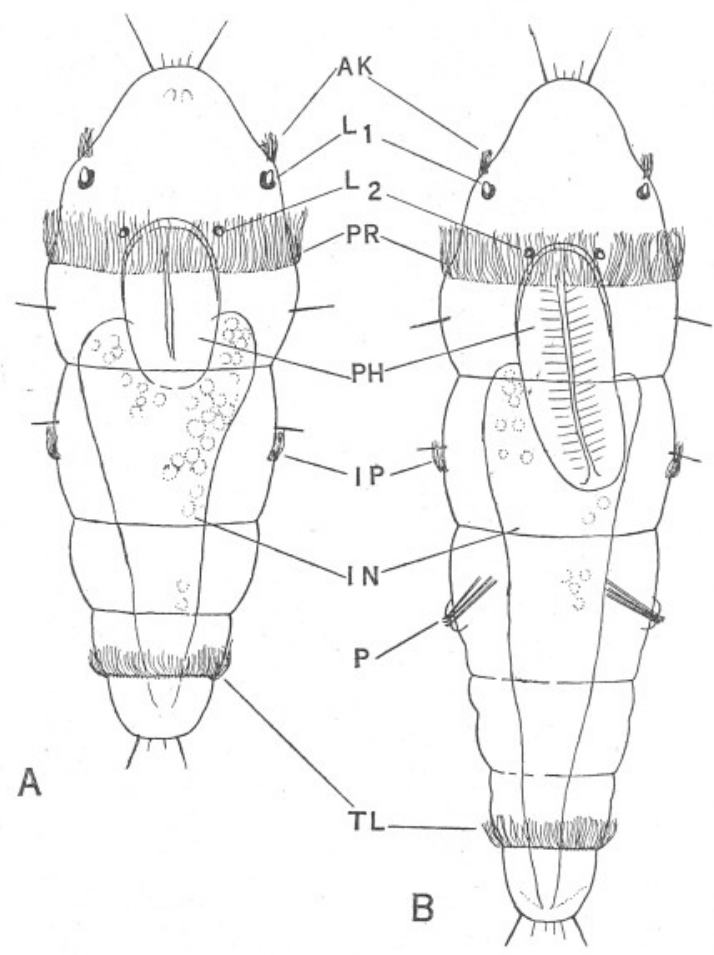

FIG. 2.-Larvæ of A. pictus, (A) one-day old and (B) six-day old, from Mr. Wilson's sketches.

AK-akrotroch; Ll-anterior pair; L2-posterior pair of eyes; IN-intestine ; IP-inter-paratroch ; $\mathrm{P}$-parapodium with setæ; PH-pharynx; PR-prototroch; TL-telotroch.

cephalic section in front of the anterior eyes, as in the older larva of Autolytus longeferiens. I think that perhaps each band is connected by a row of shorter cilia, and constitutes a complete ring, the akrotroch. The telotroch marks the boundary of the body and the pygidium. The interparatroch is already distinct in the middle of the second section of the body, and not in the third. It is present on the ventral surface only (gastrotroch). There are a number of sensory hairs at both extremities, and also spine-like tactile hairs on each side behind the prototroch, in the 
cephalic section and in the middle of the third segment, just in front of the interparatroch. The main portion of the gut consists of an ovoid stomodeal invagination and an intestine, which contains a quantity of yolk. It is important to call attention to the position of the larval pharynx, which is unmistakably within the boundary of the cephalic

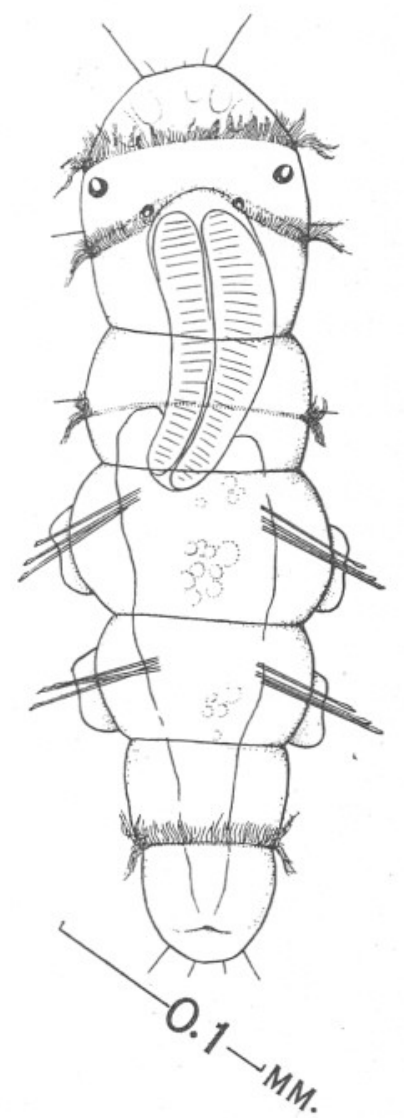

Fig. 3.-6-meric larva of $A$. longeferiens, three-day old, dorsal view.

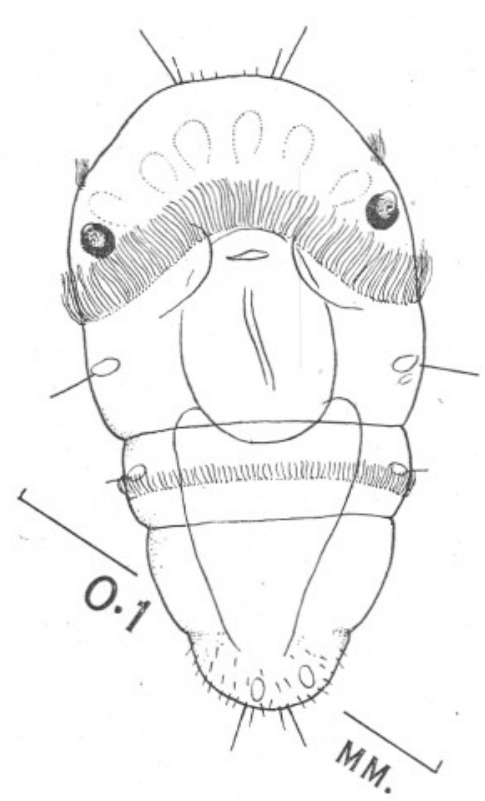

Frg. 4.-3-meric larva of A. prolifer (?) just before hatching, ventral view.

section. It scarcely extends into the second segment carrying the interparatroch.

After six days, a mono-setigerous larva $(0 \cdot 3 \mathrm{~mm}$. long) results, to which (Fig. 2B) one more segment is added at the hinder section of the body. There is no change in the front part. The first pair of bundles of setæ is now visible. They are formed in the third section of the larva. But we should not fail to notice that this is next to the segment bearing the 
interparatroch, so that it corresponds to the fourth segment of the $A$. longeferiens - larva figured by Mrs. Sexton. There is another consideration to support this view, in addition to the position of the interparatroch. As mentioned above, the stomodeal invagination comes down from the mid-ventral position of the cephalic section, instead of from the bandbearing segment. According to Malaquin (l.c., p. 392), the stomodeal invagination should have already been complete and the mouth open by this stage of development. The cephalic section is in close connection with the stomodeal invagination, and this invagination takes place both theoretically and actually between the epi- and hypo-sphere of the trochophore, and thus it seems not unreasonable to suppose that we are here dealing with a non-segmented condition of the prostomium and the buccal segment, as in the development of Nereis (see E. B. Wilson, 1892, p. 424). The buccal segment must become individualized at a later period of development (see Fig. 5).

I could not actually find a trace of the division into two segments in the cephalic section of the Syllidian larvæ in the early phases of development. The head (Fig. 3) is always completely marked off from the body by a distinct constriction lying immediately in front of the segment bearing the interparatroch. The buccal segment, therefore, constitutes morphologically an integral part of the head in this case, though, of course, it belongs to the first segment of the "Soma."

Before the stage just discussed, the larvæ are without doubt less segmented and without setæ at all. To them are referred the metatrochophores of Eusyllis assimilis drawn by Malaquin (see 1.c., pl. XIII, fig. 19) and Odontosyllis ctenostoma figured by Herpin (see l.c., pl. V, fig. 87). There are two constrictions and three divisions; these are in Autolytus prolifer (Fig. 4) the anterior cephalo-buccal section, the median first setegerous segment and the posterior somato-pygidial section. Herpin (l.c., p. 166) describes the development of the 3-meric body of Odontosyllis ctenostoma into the condition of seven segments as follows: "La plus jeune larve observée (pl. IV, fig. 87) possède déjà trois couronnes ciliées inegalement développées, dont une cephalique. Bientôt (pl. IV, fig. 88) une quatrième apparaît, en même temps que les segments s'individualisent. Au maximum de développement (pl. IV, fig. 91), les larves pélagiques d'O. ctenostoma présentent six forts couronnes ciliées." The larvæ are then 7-meric and bi-setigerous (pl. IV, fig. 92).

According to the known data, it may be stated that those larvæ in which the early developmental stages are most slowly passed through are polytrochal, cilia appearing very early and, except those of the special bands, being confined to the dorsal surface and disappearing from in front backwards. In other larvæ, in which the early stages are abbreviated, the cilia do not appear until a later period, and then only on the 
head (akro- and proto-troch) and between the last two segments (telo- or para-troch), (Malaquin, l.c., pp. 389-426, from Gravely, 1909, p. 8) with slight modifications. There is generally an interparatroch (on the ventral surface) in the middle of the future first setigerous segment. The formation of parapodia seems to commence from the second setigerous segment, and not from the first.

The 9-meric stage is followed by the 11-meric stage (Fig. 5). (The number of segments is not very important and larvæ of ten or twelve segments appear as well.) The morphology of the head is near completion, and the stomodeal invagination is divided into a long anterior pharynx proper, and a short posterior proventricular portion. The ventriculus may be differentiated also. According to Herpin (l.c., p. 166) a mono-pharyngeal condition continues, in Odontosyllis ctenostoma, until the 13-meric stage, and it is also at this time that the central cirri of the buccal segment are formed. The palpi may appear quite early in Syllis armillaris (according to Malaquin at the 7-meric stage) or their appearance is retarded, in Odontosyllis ctenostoma, until the 15-meric stage. In any case a juvenile Syllid is complete at the stage of seventeen segments, thirteen being setigerous. The pharynx then reaches the posterior border of the fifth setigerous segment, and the intestine commences from the sixth segment. In Amblyosyllis, the only further development is to specialize the individual

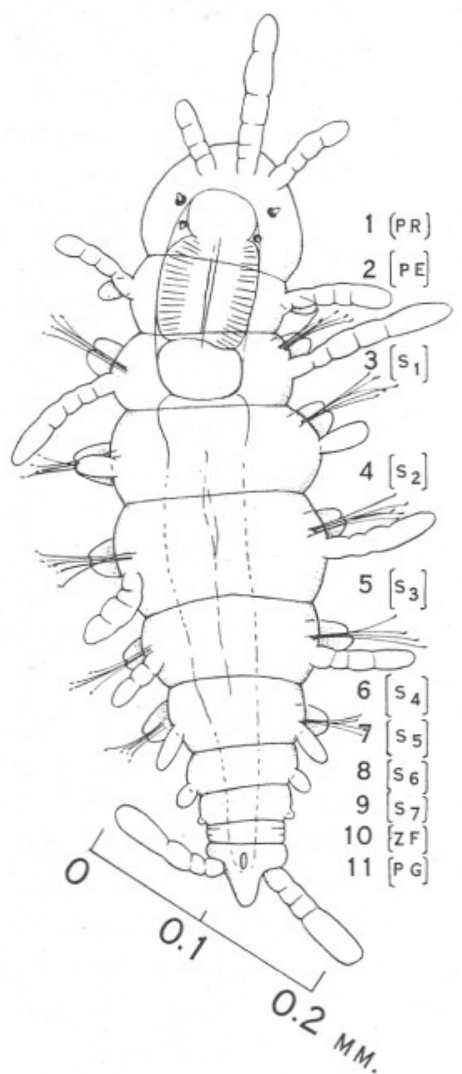

FIG. 5.-11-meric larva of Syllis sp. found on the colony of Syncoryne with Procerastea halleziana.

$1(\mathrm{PR})$ prostomium, $2(\mathrm{PE})$ peristomium, 3 (S1) first setigerous segment ... $10(\mathrm{ZF})$ growth zone, 11 (PG) pygidium. metameres, in each portion of the body parts as already determined, the growth zone being directly transformed into the penultimate tetracirrigerous segment. However, Syllids have generally more segments than seventeen, and growth must be continued. This is but a simple repetition of the same segmentation in the hinder section of the body, the manner of which is well known and requires no description in this place. 
The length of Amblyosyllis is by no means the shortest among Syllids, but perhaps of the smallest number of segments. A. lineata (=Pterosyllis formosa) as well as A. speciosa (a Japanese species described by Izuka, 1912, p. 183) consists almost constantly of seventeen segments, thirteen of which, i.e. from the third to fifteenth, are setigerous. The first segment is, of course, the prostomium, the second the peristomium, and the last the pygidium as usual, but the penultimate segment of this peculiar Syllid is also, as mentioned just above, without parapodia and bears instead two pairs of long cirri like the second segment. Malaquin (l.c., p. 423, pl. XIV, fig. 30) has figured a young "Pterosyllis " of eight segments succeeded by a pygidium; he, however, does not draw any segment without setæ between the last two segments, that is between the eighth setigerous one and the pygidium. It is, therefore, quite problematical in this case whether the penultimate, i.e. the eighth setigerous segment, represents the active zone. Malequin (l.c., p. 291), in another place, in describing the development of the Stolons of Myrianida, lays great weight upon the importance of the pygidium, so far as its first appearance in chain-formation is concerned, and Meusch (1900, p. 278) states that a new growth zone which contributes to the elongation of the Stolon, arises in Autolytus variens actually from the anal segment and in the course of its development it does not receive any contribution from the setigerous segment preceding it. Such an origin of the growth zone (in stolonisation) is entirely adverse to what I have described so far. Discussion of this problem, however, I shall not enter upon now, but postpone until another occasion, when "the Schizogamy of the Syllidæ " will be particularly considered.

But I should not postpone my acknowledgment to Dr. E. J. Allen, the Director of the Laboratory, and thanking him for help in various ways. Mrs. E. W. Sexton has helped me greatly by her generous permission to copy two larval Autolytus longeferiens from her beautiful colour sketches, both shown in Fig. 1, and to Mr. D. P. Wilson I am greatly indebted for two very young stages of Autolytus pictus shown in Fig. 2. I thank both for their kind help.

\section{REFERENCES.}

Herpin, R. 1925. Recherches biologiques sur la reproduction et le development de quelques Annelides Polychètes. Bull. Soc. Sci. Nat., d. l'Ouest, d. France, $4^{\text {e }}$ Ser. t. V. (Troisieme Partie, p. 145.)

Gravely, F. H. 1909. Polychæt Larvæ. L.M.B.C. Memoirs. (Perhaps both larvæ figured in pl. I, figs. 1 and 5, judging from the author's drawings, will not belong to those of Syllids.) 
Greeff, R. 1879. Über pelagische Anneliden von du Küste der Canarischen Inseln. Zeitschr. Wiss. Zool., Bd. XXII, S. 237.

Malaquin, A. 1893. Recherches sur les Syllidiens. Mém. Soc. Sci. et Art., Lille (Development larvaire, p. 389).

Pierantoni, U. 1903. La gestazione esterna. Contributo alla biologia ed alla embriologia dei Syllidi. Arch. Zool., vol. I.

Viguier, C. 1884. Études sur les animaux inférieurs de la baie d'Alger.

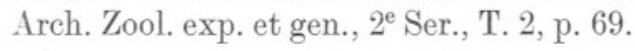

Wilson, E. B. 1892. The cell-lineage of Nereis. Journ. Morph., vol. VI, p. 424 . 
